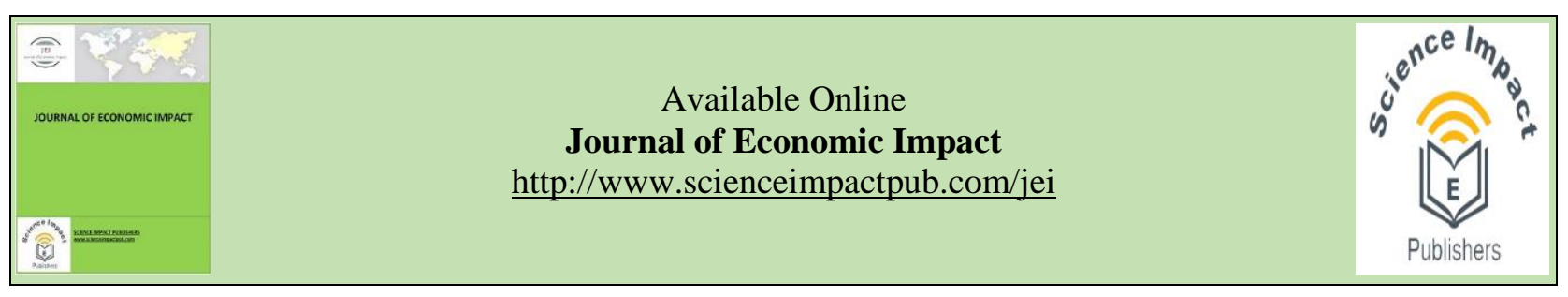

\title{
VEGETABLE PRICES POSSESS SEASONAL VOLATILITY: A CASE STUDY OF LAHORE, PUNJAB, PAKISTAN
}

\author{
Usama Haroon ${ }^{\mathrm{a}}$, Muhammad Hassan Chaudhary ${ }^{\mathrm{b}, *}$, Muhammad Aamir Shahzad ${ }^{\mathrm{c}}$, Muhammad Adnan \\ Khan $^{\text {b }}$, Nimra Nisar ${ }^{\mathrm{d}}$ \\ ${ }^{a}$ Institute of Business Administration (IBA), University of the Punjab, Lahore, Pakistan \\ ${ }^{\mathrm{b}}$ Department of International Relations, National Defence University, Islamabad, Pakistan \\ ${ }^{c}$ College of Economics and Management, Huazhong Agricultural University, Wuhan 430070, China \\ ${ }^{d}$ Department of Education, National University of Modern Languages, H-9 Islamabad (44000), Pakistan
}

\section{HIGHLIGHTS}

- The present research was conducted to determine the seasonal volatility of four important vegetables in Pakistan.

- The price flexibility coefficient was estimated along with the seasonal behavior concerning prices for perishable vegetables.

- The results indicate that the irregular seasonal and cyclical fluctuations observed every year.

- Price fluctuations for onion, tomato, potato, and cabbage are seasonal.

- After the harvest, low prices were observed while price were observed high before the start of the season when relative supply shortage occurs.

- The study suggests that prices can be controlled by intervening in the market by increasing supply and production using new technology and high yielding seed varieties.

ABSTRACT
The present research was conducted to determine the seasonal volatility of four important vegetables in
Pakistan. The four vegetables included in this study are onion, tomato, potato, and cabbage. The first three
of which are necessary kitchen items in the food consumption of the country. The study area is comprised
of the Lahore district of the Punjab province which is the most populous city in the province and the major
producer of the vegetables in the country. Secondary data of the year 2010 and 2011 about prices and quantity
of these four vegetables were collected from the market committee and agriculture marketing information
system Lahore. The price flexibility coefficient was estimated along with the seasonal behavior concerning
prices for perishable vegetables. The results indicate that the irregular seasonal and cyclical fluctuations
observed every year. Price fluctuations for onion, tomato, potato, and cabbage are seasonal. After the harvest,
low prices were observed while price were observed high before the start of the season when relative supply
shortage occursand vice versa. Hence, the study suggests that prices can be controlled by intervening in the
market by increasing supply and production using new technology and high yielding seed varieties.

Keywords: Volatility, seasonal variations, moving average, price fluctuation, Pakistan.

Received: Aug 19, 2020; Accepted: Aug 28, 2020; Published: Aug 31, 2020.

* Correspondence: Department of International Relations, National Defence University, Islamabad, Pakistan.

Email: mh.chaudhary999@gmail.com

\section{Introduction}

The necessary kitchen items in Pakistan are potato, cabbage, onion, and tomato. These are perishable commodities in nature (Shahzad et al., 2019a). The price elasticity of demand for tomato, potato, and onion is very high because these are frequently used vegetables, while the cabbage has a nearly inelastic demand. Vegetable production is riskier compared to major crops. Since vegetables are highly susceptible to disease and insect attacks and require specific skills and knowledge to perform farm management practices. On the other hand, price fluctuations also determine 
the allocation of cultivation area of vegetables and affect the profitability of vegetable production to a great extent (Mari, 2009). Vegetable production in Pakistan has an $80 \%$ marketable surplus (Mukhtar, 2004).

In Pakistan per day per capita vegetable consumption is half of the healthy recommended level which is 200 gram per capita per day (Farooq and Ali, 2003). Improving vegetable productivity will keep the prices of vegetables within access to urban and rural consumers. The price changes always affect the production quantity. The price of the crop is mainly determined by its supply due to inelastic demand (Toaha, 1974). Vegetables have inelastic demand. Therefore, a high variation in the supply of the crop causes variability in prices (Rani et al., 2012). The price elasticity of demand of vegetables shows seasonal volatility (Najmi, 1991). The evidence of research involving the measurement of price flexibility in the era from the 1900 s to 2000s was found in different studies (Mills, 1927; Houck, 1966; Huang, 1988; Toaha, 1974; Driskill \& Sheffrin, 1986; Tobin, 1993; Kandil, 1996; Sorensen, 1999; De Brauw et al., 2000). These studies estimated the price flexibility impact on the demand and supplies of crops and the markets functioning and storage capabilities. The price cap reduces price volatility (Francis et al., 2002). Price flexibility is useful in production environments and price customization (Charnsirisakskul et al., 2006).

Market functioning can be improved by evolving new harvesting techniques and marketing technology (Mukhtar, 2004). The long-run relationship was found across regional markets in Pakistan (Lohano and Mari, 2005). Moreover, endogenous price flexibility can lead to a significant change in welfare performance (Senay and Sutherland, 2006). Further, Huang (2006) explained flexibilities from a directly estimated inverse demand system. The domestic market openness with international markets is important in determining the domestic price level (Schnepf, 2006). Furthermore, Alimi (2005) showed low output prices and high perishable nature of vegetables in the rainy season were the highestranked constraints in okra production. A particular pattern of seasonal price change for tomatoes for 2006 indicates $50-100 \%$ price increases are in the wet season. If prices are too low, much of the harvestable crop is left in the field (Daugovish et al., 2007). The cross effects of substitutions and complementarity tell the true price elasticity and flexibility reciprocal (Houck, 1965). Different studies were described subsidies, expenditure elasticity, and price flexibilities (Dong and Lin, 2009; Adjemian and Smith, 2012; Chua and Tomek, 2010; Haq et al., 2011). Rani et al. (2012) explained the growth rate of prices of major pulses. The efficient estimates of the contract price were provided by the seasonal models (West, 2012). Furthermore, Adjemian and Smith (2012) studied the regression model for price estimations, and Thornsbury and Jerardo (2012) illustrated lower prices observed at the start of the crop year.

The present study was conducted to fill the gap and hypothesize that the price flexibility and volatility of vegetables especially onion, tomato, potato, and cabbage are seasonal in nature as against the alternative. The study utilizes secondary from government sources i.e. agricultural marketing information system, market committees, and taken Lahore, Punjab, Pakistan as a case study. The study supports the hypothesis that the prices of perishable vegetables exhibit seasonal volatility. The preceding sections will describe Materials and Methods, Result and Discussion and Summary.

\section{Methodology}

This study measures the seasonal volatility and variations in vegetable prices in Lahore, Punjab, Pakistan. The study consists of the city of Lahore from Punjab, Pakistan as the case study because it is the major contributor in the economy of Punjab. Lahore is the largest contributor in the production of potatoes and other vegetables in the Punjab. Also, it is the biggest wholesale market in Punjab province.

The study used secondary data for prices. Four vegetables including onion, tomatoes, potatoes, and cabbage are the primary focus of this study. The source of the data was Directorate of Agriculture (Economics \& Marketing) Lahore for the years 2010 and 2011.

\section{Coefficient of price flexibility}

The responsiveness of consumers in quantities due to price changes is the price elasticity. In earlier literature, the demand and supply coefficients were discussed in detail. While the direct correlation between elasticity of demand and price flexibility is not discussed explicitly. Elasticity measures response effect price change on quantity. The inverse of price elasticity measures the responsiveness of price change due to quantity 
change. The inverse elasticity relationship is known as price flexibility. The lower absolute limit of reciprocal of direct price flexibility is a lower absolute limit of direct price elasticity. The inelastic demand characterizes more flexible prices through greater flexibility coefficient.

$\epsilon_{P F C}=\frac{P_{2}-P_{1}}{P_{1}} / \frac{Q_{2}-Q_{1}}{Q_{1}}=\frac{\% \text { Change in } \mathrm{P}}{\% \text { Change in } \mathrm{Q}}=\frac{1}{\epsilon_{D}}$

Price flexibility $(\mathrm{PF})=$

$\frac{1}{\% \text { Changein } Q / \% \text { Changein } P}=\frac{1}{\epsilon}$

If the price elasticity of demand for a product were -0.2 , the price flexibility would be:

$$
\mathrm{PF}=\frac{1}{-0.2}=-5
$$

That is, if the quantity available would increases by $1 \%$ then the corresponding reduction in prices will be $5 \%$. In the inelastic range of demand curve, the absolute values of price flexibility are substantially greater than one, meaning that a 1 percent change in quantity will generate a price change in excess of 1 percent. Thus, in the inelastic range of the demand curve, prices are much more volatile than the quantities, and quantities are much more volatile than prices in the elastic range of demand. The direct price flexibility reciprocal is an indication of a minimum percentage decrease in quantity demanded due to a $1 \%$ increase in the price level (Houck, 1966).

\section{Measuring seasonal variations (Seasonality)}

The phenomenon that occurs cyclically over 12 month's production cycle for crops is known as seasonality. It is a specific type of cycle and is different from the trend forces. It is a self-sustaining and continuous pattern of prices that occurs over any length of time. The market shocks such as droughts, drastic policy changes, and other events can cause prices to act contra seasonal (Ferris, 2008). There are a variety of methods for estimating price seasonality. Probably the easiest and quickest method is the use of simple averages.

Simple average: On simple average calculation, the seasonal price index can be calculated by using different steps. First by sorting and arrangement of prices by months for each vegetable per year and then to calculate the average price of two years of each month over the whole data. After that a two- year average was used as a base and to construct an index of price by dividing the every two year average monthly prices by an overall two-year average. Then the newly formed index is interpreted as the monthly expected \%age deviation from the expected average prices. To determine the zone of seasonal instability or range of instability divide the price of every month of the market year by annual average prices for that specific year and choosing the highest and the lowest value for each month as an interval of range of seasonal instability. After, calculating the individual monthly percentages the simple average estimate for every month is the index of price seasonality.

Moving average: There are several ways that a centered moving average can be constructed for purposes of defining seasonal price patterns. It is necessary to use an uneven number of periods for purposes of centering the moving average, the normal approach to a seasonal index is to use 13 months of information. That is, one-half of the prices of January in one year and for January of the following year would be added to the prices of February through December, divided by twelve for an average. The construction begins with the calculation of a 12 month moving total. The first 13 months of price data are used, summing the middle 11 months and adding to this half of the first thirteenth months, with the resulting total posted at the midpoint of that 13-month interval. Then half of each of the first and the second months of the data are deducted from the total and half the thirteenth and fourteenth months are added, with the resulting sum being posted at the midpoint of the new 13month interval or the eighth month of the data. This process is continued until a twelve months total has been calculated for each month in the period for which the seasonal of the price index is to be constructed. Once the calculation of the 12-month moving total has been accomplished, each figure is divided by 12 to get the 12 -month moving average that will serve as the base for the seasonal price index (John, 1994).

\section{Results and discussion}

The data shows that overall vegetable prices are volatile and have increased over time. Vegetable prices were lowest during the harvesting period starting from December to May. While prices are lower from January to June.

It is evident from Table 1 that the vegetable prices are lower when the adequate supply is 
available in the market. Period of pre-harvest experienced higher prices than the post-harvest. The vegetable prices are highly volatile and tomatoes showed the highest fluctuations. The tomato prices have the highest percentage gap in prices during the season and after season. The storage of crops can reduce volatility in prices. These findings are consistent with the findings of Mills (1927), which revealed that the price changes due to a change in the quantity supplied. The period of higher supply faces fewer prices and vice versa.

Table 1: Monthly average vegetable wholesale prices (Prices in Pak rupees/quintal)

\begin{tabular}{lcccccccc}
\hline \multicolumn{3}{c}{ Year 2010 } & \multicolumn{4}{c}{ Year 2011 } \\
\hline Month/Crop & Potato & Onion & Tomato & Cabbage & Potato & Onion & Tomato & Cabbage \\
\hline Jan & 950 & 1883 & 1217 & 1138 & 1054 & 2939 & 4902 & 1001 \\
Feb & 917 & 1733 & 1417 & 959 & 1066 & 1955 & 2625 & 875 \\
Mar & 1000 & 1967 & 1258 & 871 & 1098 & 1194 & 2515 & 840 \\
App & 983 & 2367 & 1774 & 904 & 1450 & 1094 & 1912 & 890 \\
May & 1700 & 1858 & 1508 & 1590 & 2700 & 1012 & 788 & 1440 \\
Jun & 2142 & 1467 & 1433 & 1446 & 2325 & 877 & 1643 & 1320 \\
July & 2567 & 1550 & 2975 & 2907 & 2734 & 1373 & 1643 & 2005 \\
Aug & 3917 & 2150 & 4683 & 4619 & 2996 & 1905 & 3033 & 3200 \\
Sept & 2725 & 3000 & 4033 & 2733 & 2670 & 2435 & 3856 & 1807 \\
Oct & 2458 & 3292 & 2883 & 2984 & 2677 & 3495 & 5585 & 2132 \\
Nov & 2483 & 5883 & 2933 & 3582 & 2370 & 3871 & 5237 & 3606 \\
Dec & 1283 & 4167 & 4208 & 2856 & 1128 & 2687 & 4159 & 2504 \\
\hline
\end{tabular}

Table 2: Results for the price flexibility and elasticity coefficients for potato vegetable in year 2010

\begin{tabular}{lcccc}
\hline Time & $\begin{array}{c}\text { Monthly average price } \\
\text { per quintal (PKR.) }\end{array}$ & $\begin{array}{c}\text { Monthly average } \\
\text { quantity supplied (tons) }\end{array}$ & $\begin{array}{c}\text { Price } \\
\text { elasticity }\end{array}$ & $\begin{array}{c}\text { Coefficient of } \\
\text { Price flexibility }\end{array}$ \\
\hline January & 950 & 4588 & -- & -- \\
February & 917 & 4710 & -0.76 & -1.3 \\
March & 1000 & 3964 & -1.74 & -0.57 \\
April & 983 & 4025 & -0.90 & -1.10 \\
May & 1700 & 3740 & -0.097 & -10.30 \\
June & 2142 & 3250 & -0.50 & -1.98 \\
July & 2567 & 3020 & -0.35 & -2.80 \\
August & 3917 & 2775 & -0.15 & -6.48 \\
September & 2725 & 2930 & -0.18 & -5.44 \\
October & 2458 & 3095 & -0.089 & -1.73 \\
November & 2483 & 3155 & 1.9 & 0.52 \\
December & 1283 & 3445 & -0.19 & -1.24 \\
\hline
\end{tabular}

\section{Price flexibility of vegetables}

The concept of price flexibility, which is a change in prices due to change in quantity indicates that if an increase in prices is less than increased cost then prices reflect a higher degree of flexibility and volatility. If the flexibility coefficient is less than 1 , then it is considered flexible. While if the flexibility coefficient is greater than 1 then it's considered inflexible.
Price flexibility coefficient for potatoes: The price flexibility coefficient for potatoes showed that in the month of February if there would be a $1 \%$ increase in the quantity supplied then prices may reduce up to $1.3 \%$. The price flexibility coefficient is highest (-10.30) in April and May. While prices of potato are inflexible in November (Table 2).

The results reported in Table 2 for the demand price elasticity for potatoes indicate that in November, the price elasticity is greater than 1 but 
the price flexibility coefficient is inflexible due to the positive value of price elasticity. In the inelastic range of demand, the absolute values of price flexibilities are substantially greater than one; it interprets that a 1 percent change in quantity will generate a price change above 1 percent. Price flexibility in May (-9.7) which the highest value is in the year but in June the value of price flexibility is much reduced. In October the estimated value of price flexibility coefficient is non-negative which indicates inflexible prices because the price elasticity of demand for potatoes in October is elastic with the value of 8.9. The results are consistent with the findings of Richard (2012) which revealed, in the inelastic range of demand, prices are much volatile than quantities, and quantities are more volatile than prices in the elastic range of demand. The potato prices were at the lowest during the supply period starting from December to May. Potato is the main autumn season crop which is harvested from January to March. Therefore, the prices of potatoes remains less during these months.

Price flexibility coefficient for tomato: It is generally observed that the tomato prices are lower during the start of the season from January to May. While in June there is a rapid increase which reaches at highest during august (off-season). The prices can be stabilized by regulating the supplies in the markets.

Table 3: Results for price flexibility and elasticity coefficient for tomato vegetable in year 2010

\begin{tabular}{lcccc}
\hline Time & $\begin{array}{c}\text { Monthly average price per } \\
\text { quintal (Pak rupees) }\end{array}$ & $\begin{array}{c}\text { Monthly average } \\
\text { quantity supplied } \\
\text { (tons) }\end{array}$ & Price elasticity & $\begin{array}{c}\text { Coefficient of } \\
\text { price flexibility }\end{array}$ \\
\hline January & 1217 & 75 & -- & -- \\
February & 1417 & 68 & -0.56 & -1.76 \\
March & 1358 & 71 & -1.05 & -0.94 \\
April & 1774 & 58 & -0.59 & -1.67 \\
May & 1508 & 63 & -0.57 & -1.73 \\
June & 1433 & 72 & -2.86 & -0.34 \\
July & 2975 & 53 & -0.24 & -4.07 \\
August & 4683 & 39 & -0.46 & -2.17 \\
September & 4033 & 41 & -0.36 & -2.70 \\
October & 3883 & 48 & -4.59 & -0.21 \\
November & 2933 & 60 & -1.02 & -0.97 \\
December & 4208 & 40 & -0.76 & -1.30 \\
\hline
\end{tabular}

The coefficient of the price elasticity of demand for tomato reported in Table 3 is inelastic and the price flexibility coefficient inflexible. If there is 1 percent increase in the quantity supplied than it causes a 4.07 percent reduction in the prices. When prices rise, the sales from storage are added to markets, preventing prices from rising.

Price flexibility coefficient for onions: The analyses revealed that the lowest prices were observed during the month from May to August when the onion is supplied from Punjab province. It increases the overall supply in the markets. However, the highest prices were observed from the month of September to October when the onion is supplied from the Balochistan province. And the price gradually rises because the time is approaching towards the non-harvesting period.

In Table 4 , the value of the price flexibility coefficient is higher from October to November (3.01). This is interpreted as the one percent change in the quantity supplied causes a $3.01 \%$ decline in the prices. However, the value of the coefficient is observed lower in the month of June which is the peak harvesting time. The monthly demand for the onion is relatively more price elastic than the annual demand. The results are consistent with the finding of Huang (2006).

Price flexibility coefficient for cabbage: Cabbage is a cool-season biennial vegetable crop. The price elasticity of demand for cabbage is inelastic because 
this crop is not an essential item of Pakistani kitchens.

Table 4: Results for price flexibility and elasticity coefficients for onion in year 2010

\begin{tabular}{lcccc}
\hline Time & $\begin{array}{c}\text { Monthly average } \\
\text { price per quintal } \\
\text { (Pak. rupees) }\end{array}$ & $\begin{array}{c}\text { Monthly average } \\
\text { quantity supplied } \\
\text { (tons) }\end{array}$ & Elasticity of price & $\begin{array}{c}\text { Coefficient of } \\
\text { price flexibility }\end{array}$ \\
\hline January & 1879 & 74 & -- & -- \\
February & 1743 & 69 & -2.26 & -0.45 \\
March & 1966 & 70 & -1.81 & -0.56 \\
April & 2368 & 59 & -0.55 & -1.85 \\
May & 1859 & 64 & -0.25 & -4.17 \\
June & 1468 & 73 & -3.38 & -0.28 \\
July & 1551 & 54 & -1.01 & -0.98 \\
August & 2149 & 38 & -1.05 & -0.96 \\
September & 3001 & 42 & -0.52 & -1.94 \\
October & 3293 & 49 & -1.19 & -0.85 \\
November & 5893 & 61 & -0.34 & -3.01 \\
December & 4177 & 41 & 0.54 & 1.86 \\
\hline
\end{tabular}

Table 5: Results for price flexibility and elasticity coefficient for cabbage vegetable in year 2010

\begin{tabular}{lcccc}
\hline Time & $\begin{array}{c}\text { Monthly average } \\
\text { price per quintal } \\
\text { (PKR) }\end{array}$ & $\begin{array}{c}\text { Monthly average } \\
\text { quantity supplied } \\
\text { (tons) }\end{array}$ & Price elasticity & $\begin{array}{c}\text { Price flexibility } \\
\text { coefficient }\end{array}$ \\
\hline January & 1001 & 4.5 & -- & -- \\
February & 875 & 7 & -4.41 & -0.22 \\
March & 840 & 8 & -3.57 & -0.13 \\
April & 890 & 7.7 & -0.63 & -1.58 \\
May & 1440 & 2.8 & -1.02 & -0.97 \\
June & 1320 & 3.5 & -3 & -0.33 \\
July & 2005 & 2.2 & -0.71 & -1.39 \\
August & 3200 & 1.3 & -0.68 & -1.45 \\
September & 1807 & 2 & -1.23 & -0.80 \\
October & 2132 & 1.75 & -0.69 & -1.43 \\
November & 3006 & 1.48 & -0.37 & -2.65 \\
December & 2504 & 1.67 & -0.76 & -1.30 \\
\hline
\end{tabular}

In Table 5, the highest value of the price flexibility coefficient is in November is -2.65 . There is a higher level of price fluctuation in cabbage prices as compared to the other vegetable crops but in 2011 there are fewer changes in the prices as compared to the prices of the last year. The lowest value of the coefficient is -0.13 in April. The study by Toaha (1974) revealed high price fluctuations and extensive malpractices due to lack of effective market legislation and non-regulated markets favored traders and low producers share in consumer rupee.

\section{Results for seasonality}

This seasonality frequently originates in the biological realities that regulate production. There are two different methods that we used to check the seasonal behavior of potato, onion, tomato, and cabbage. One is a simple average approach and the second is the moving average approach used in this study.

Result for potatoes (Simple average): The results in Fig. 1 suggest that the potatoes prices vary in the year 2010 and 2011 both year and also causes variations in the seasonal indices. The average prices were lower during harvesting (February) and higher during the non-harvesting season (August). 
Thus, the highest value of the seasonal index is 111.4 for May. The May seasonal index value of 111.4 is bounded by a range of seasonal instability of 50.2 to 175 (Fig.1).

Result for tomatoes (Simple average): The results for the tomatoes indicate that the January seasonal
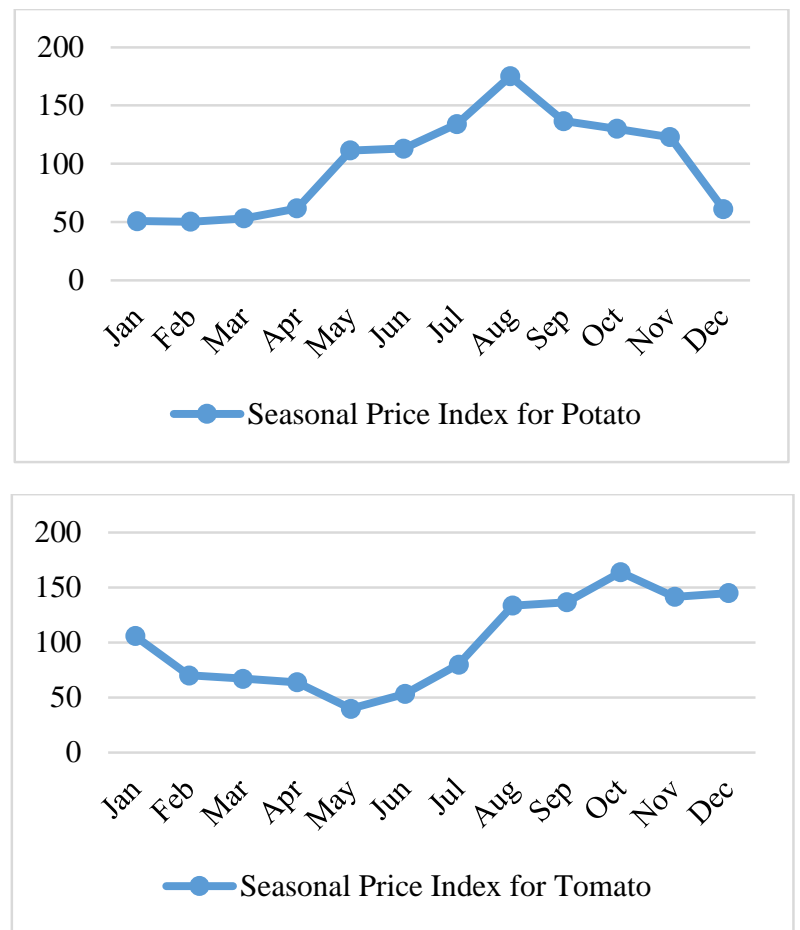

index value is 105.9 which suggests higher prices in the month of January and these are about $5.9 \%$ higher than the seasonal average price. January seasonal index value (105.9) bounded by a range of seasonal instability of 39.76 to 163.9 . It is apparent that the index is fairly unstable during July to December during the non-harvesting season.

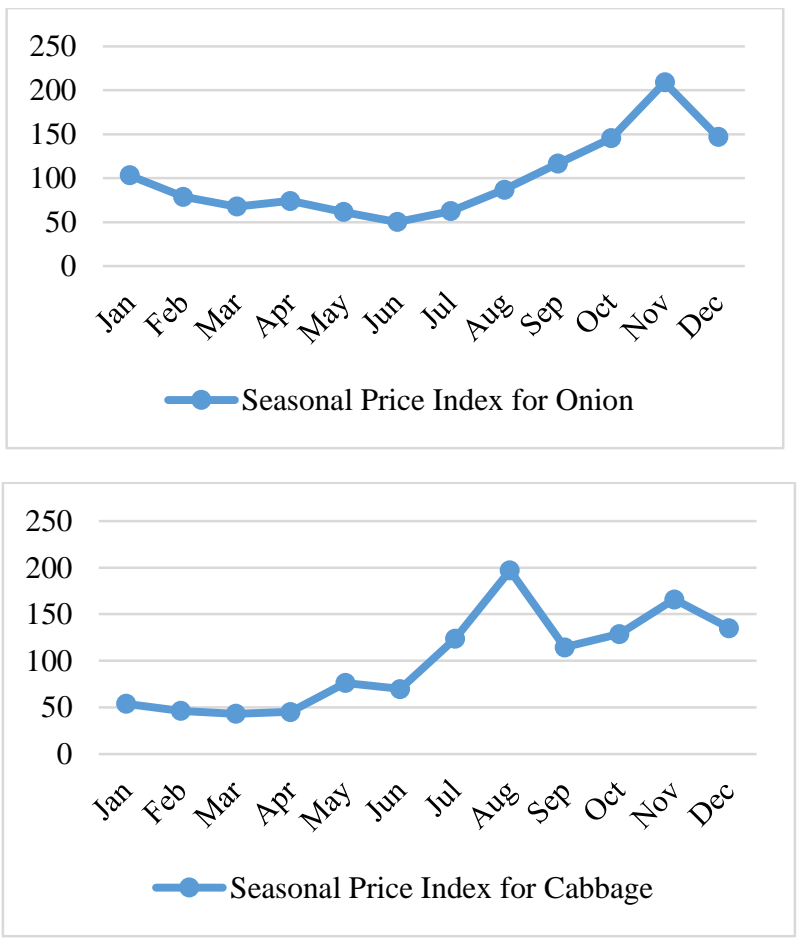

Fig. 1: Seasonal index for vegetables (Simple Average)

Source: Graph has been constructed for the secondary data on Seasonality

Result for onions (Simple average): Volatile fluctuations in the prices of onions are cyclical and seasonal and these are observed in both years 2010 and 2011 under study. The results revealed that seasonal index stands at 103.3 for the month of January which suggests that in January we should expect at January prices rise up to $3.3 \%$ than the average seasonal prices. January seasonal index value (103.3) bounded by a range of seasonal instability of 50.23 to 209.1 . That is, the lowest price of June has been within the years of our investigation is 50.23 percent of the season average price. The highest is 109.1 percent above the season average price (Fig. 1).

Result for cabbage (Simple average): The value of the seasonal index is 123.8 for July suggests that to normally expect July prices in any cabbage marketing year to be about 23.8 percent higher than the season average price. January seasonal index value (123.8) bounded by a range of seasonal instability of 43.12 to 197.1 . That is, the lowest price of March has been within the years of our investigation is 43.12 percent of the season average price. The highest is 197.1 percent above the season average price (Fig. 1).

\section{Moving average approach for vegetables}

The moving average approach for potatoes shows that monthly moving seasonal index for potato for July is 133.21 . It shows, in July the price of potatoes is 33.21 percent higher than the moving average total. The lowest value is in July (50.35) which means this month the prices are 50 percent to the month moving total. The moving average based index emphasizes the phenomena that the greatest stability in seasonal potato prices occur immediately preceding and during harvest.

The moving average approach for tomato shows that the highest seasonal price index value is 
376.91 which means that the prices are 276.91 percent less than the moving average total. The range of instability is from 62.47 to 376.91 (Fig. 2).

The moving average approach for onion shows that In July the value of the moving average index
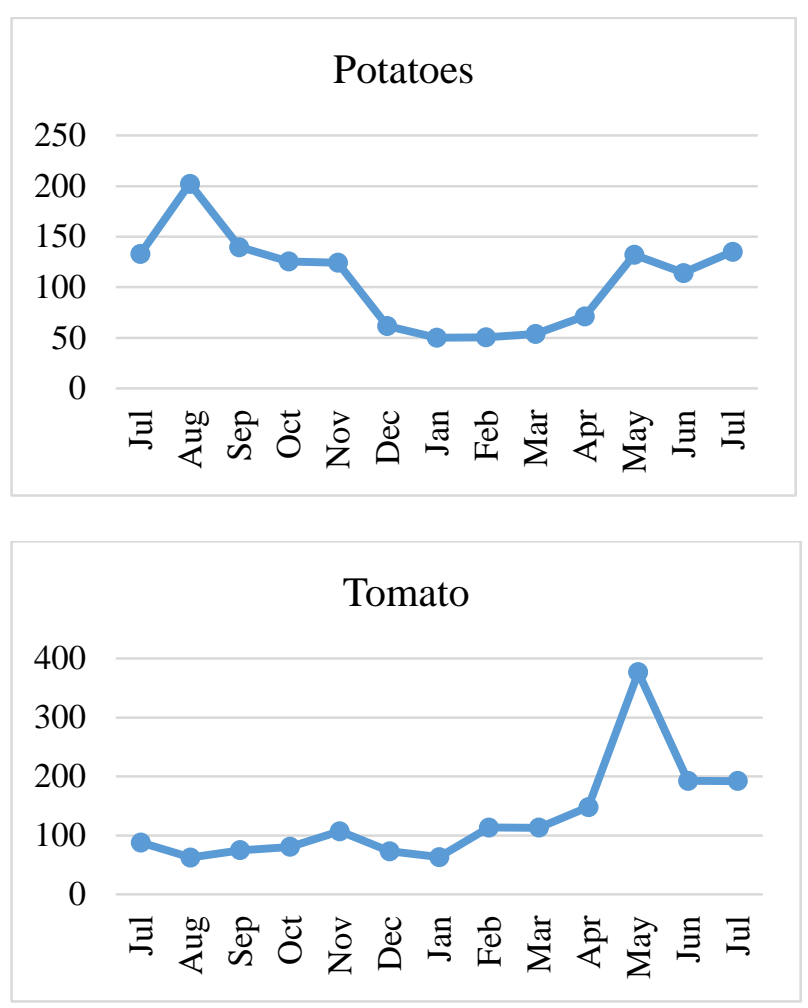

is 59.4. The peak value of the index is in November is 230.88 which means that in this month the prices of onion in the market are 130.88 percent higher than the total moving average. The range of instability is between 39.99 and 230.88 .

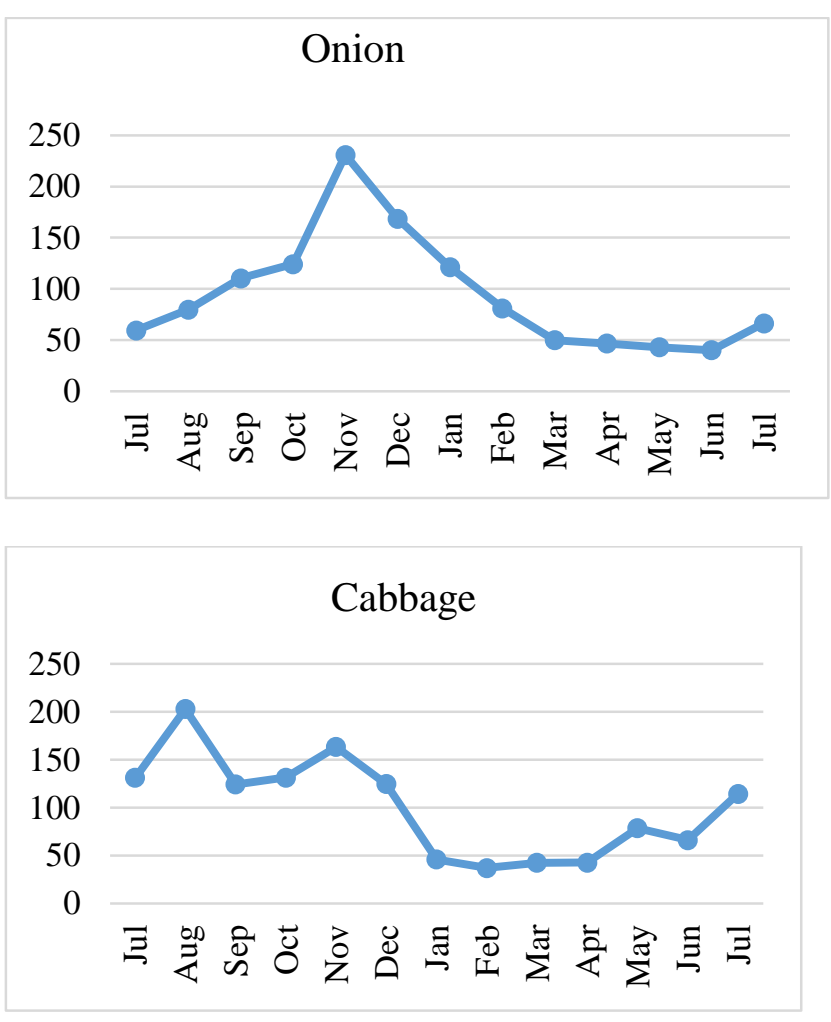

Fig. 2: Monthly moving average seasonal index for vegetables

Source: Graph has been constructed for the secondary data on Seasonality

The moving average approach for cabbage shows that In July the value of the moving average index is 131.20. The month of August showed the peak value of the index is in the month of is 202.83 which means that in this month the prices of onion in the market are 102.83 percent higher than the total moving average. The lowest value of this moving average approach of cabbage is 37.04 in February. The range of instability is between 37.04 and 202.83 (Fig. 2).

\section{Discussion}

Historically, due to the annual nature of the crop cycle, vegetables possess seasonal vitality in prices. In the harvesting season due to abundant supply, the vegetable prices remain lower. However, due to a lack of production after the season, the prices show higher movements at the end of the marketing year. Vegetable prices vary greatly and volatile determined by the demand and supply forces.
Different seasonal indexes are relevant in these different situations. When observed along supply and demand and marketing concepts seasonal price fluctuations can be used as a guide for developing marketing plans. The study by Horo et al. (2016) revealed seasonal decomposition of prices indicates that the index was high during December but varies between May to July for attaining the minimum. Moreover, there exists large food price seasonality in Africa despite of lower estimates that were reported in earlier published literature and diverse across regions, crops and market places (Gilbert et al., 2016). During demand peaks, prices of seasonal products fall and declining agriculture input prices are not driven prices to fall. An increase in the seasonal demand reduces the marketing informative costs by retailers and may increase market information ad higher price sensitivity to buyers (MacDonald, 2000). During seasonal demand peaks for a product the prices fall on average found by 
Chevalier et al. (2003). For selling the product the seasonal price patterns help greatly to establish time deadlines. For example, the higher price periods can be used for selling the crop but storage cost must be considered while selecting a selling timeline. Finally, the results show that the change in the price of these four vegetables monthly is due to the supplied quantity of these vegetables in the market. In the harvesting, the trend of prices was lower but in the non-harvesting season, the price is high due to the availability of these vegetables either by imports or buying from other locations or provinces.

\section{Conclusions}

Prices of vegetables fluctuate due to production instability. In this research, we estimated seasonal volatility and flexibility in vegetable prices in the city Lahore of Punjab, Pakistan. The study takes potatoes, tomatoes, onions, and cabbage as the main vegetables for analysis. It further explores the seasonality trend of prices during the 2010 and 2011 years using monthly data of prices. Analyses revealed that large price volatility exists in vegetable prices and the seasonal pattern is observed in its price movements. Improvement in storage for these vegetables can help to stabilize prices. Normally the price is less in February and March which gradually increases till September. The problem of price fluctuation may aggravate with the absence of a price support system (Shahzad et al., 2019b) and there is a dire need for market extensions in this regard. Thus, the level of prices in vegetables in the short run is unstable. This study suggests that policymakers must forecast the prices of vegetables. If the production is inadequate then it is recommended to increase production via raising more crop areas under cultivation, use of new high yielding technology, and using existing resources efficiently.

\section{References}

Adjemian, M.K., Smith, A., 2012. Using USDA forecasts to estimate the price flexibility of demand for agricultural commodities. American Journal of Agricultural Economics, 94(4), 978-995.

Alimi, T., 2005. Economics of monocropping okra under tropical conditions during the rainy and dry seasons. Journal of Vegetable Science, 11(2), 1934.

Charnsirisakskul, K., Griffin, P.M., Keskinocak, P., 2006. Pricing and scheduling decisions with leadtime flexibility. European Journal of Operational Research, 171(1), 153-169.

Chevalier, J.A., Kashyap, A.K., Rossi, P.E., 2003. Why don't prices rise during periods of peak demand? Evidence from scanner data. American Economic Review, 93(1), 15-37.

Chua, H.W.P., Tomek, W.G., 2010. On the relationship of expected supply and demand to futures prices. Paper presented at NCCC-134 Conference on Applied Commodity Price Analysis, Forecasting, and Market Risk Management. St. Louis.

Daugovish, O., Cahn, M., Koike, S., Natwick, E., Cantwell, M., Takele, E., 2007. Cabbage production in California, UC Vegetable Research \& Information Center, Division of Agriculture and Natural Resources, University of California.

De Brauw, A., Huang, J., Rozelle, S., 2000. Responsiveness, flexibility, and market liberalization in China's agriculture. American Journal of Agricultural Economics, 82(5), 11331139.

Dong, D., Lin, B.H., 2009. Fruit and vegetable consumption by low-income Americans: would a price reduction make a difference? United States Department of Agriculture, Economic Research Report Number 70.

Driskill, R.A., Sheffrin, S.M., 1986. Is price flexibility destabilizing? The American Economic Review, 76(4), 802-807.

Farooq, U., Ali, M., 2003. Combating micronutrient deficiency in Pakistan by increased vegetable use. Asian Vegetable Research and Development Center (AVRDC), Shanhua, Tainan, Taiwan 741, ROC, Draft Paper.

Ferris, J.N., 2008. Seasonal cash price patterns for selling Decisions on corn soybeans and wheat, North Central Region Extension Publication, no. 217.

Francis, N., Chiu, H., Björnsson, H., 2002. Quantifying price flexibility in material procurement as a real option. CIFE Seed ProjectReal Options in Material Procurement Contracts October, 2002.

Gilbert, C.L., Christiaensen, L., Kaminski, J., 2017. Food price seasonality in Africa: measurement and extent. Food policy, 67, 119-132.

Haq, Z., Nazli, H., Meilke, K., Ishaq, M., Khattak, A., Hashmi, A.H., Rehman, F.U., 2011. Food demand patterns in Pakistani Punjab. Sarhad Journal of Agriculture, 27(2), 305-311.

Horo, A., Sendhil, R., Das, J., 2016. Integration and price transmission in wheat markets of Uttar 
Pradesh, India. Indian Journal of Agricultural Marketing, 30(3), 168-178.

Houck, J.P., 1966. A look at flexibilities and elasticities. Journal of Farm Economics, 48(2), 225-232.

Huang, K.S., 1988. An inverse demand system for US composite foods. American Journal of Agricultural Economics, 70(4), 902-909.

Huang, K.S., 2006. A look at food price elasticities and flexibilities. Economic Research Service, U.S. Department of Agriculture, Washington, DC.

Houck, J.P., 1965. The relationship of direct price flexibilities to direct price elasticities. Journal of Farm Economics, 47(3), 789-792.

John, W.G., 1994. Agricultural prices analysis and forecasting, pp. 137. John Wiley \& Sons, Inc. New York.

Kandil, M., 1996. Price flexibility and output variability: what do we learn from disaggregate data? Journal of Economics and Business, 48(2), 117-139.

Lohano, H.D., Mari, F.M., 2005. Spatial price linkages in regional onion markets of Pakistan. Journal of Agriculture and Social Sciences, 1, 318-321.

MacDonald, J.M., 2000. Demand, information, and competition: why do food prices fall at seasonal demand peaks? The Journal of Industrial Economics, 48(1), 27-45.

Mari, F.M., 2009. Structure and efficiency analysis of vegetable production and marketing in Sindh, Pakistan. Ph.D. Thesis, Department of Agricultural Economics, Faculty of Agricultural Social Sciences, Sindh Agriculture University, Tando Jam.

Mills, F.C., 1927. Relations between Prices and price-determining factors: price flexibility in the behavior of prices (pp. 140-151). NBER.

Mukhtar, M.M., 2004. Agricultural marketing system and trade enhancement: Issues and policies. Pakistan Journal of Agricultural Economics, 5(1), 17-26.

Najmi, Y., 1991. Price responsiveness of household demand in Pakistan. M. Phil Thesis, Department of Economics, Quaid-i-Azam University, Islamabad.

Richard, M.A., 2012. Statistical measurement of price flexibility. The Quarterly Journal of Economics, 56(3), 497-502.

Rani, S., Shah, H., Ali, A., Rehman, B., 2012. Growth, instability, and price flexibility of major pulses in Pakistan. Asian Journal of Agriculture and Rural Development, 2(2), 107-112.

Schnepf, R., 2006. Price determination in agricultural commodity markets: a primer. Congressional Research Service, The Library of Congress.

Senay, O., Sutherland, A., 2005. Can endogenous changes in price flexibility alter the relative welfare performance of exchange rate regimes? (No. w11092). National Bureau of Economic Research.

Shahzad, M.A., Razzaq, A., Aslam, M., Gulzar, M.F., Nisar, N., 2019a. Opportunities for agricultural trade in the context of the ChinaPakistan Economic Corridor. Business and Economic Research, 9(1), 263-282.

Shahzad, M.A., Razzaq, A., Qing, P., 2019b. On the wheat price support policy in Pakistan. Journal of Economic Impact, 1(3), 80-86.

Sorensen, C., 1999. Seasonality in agricultural commodity futures. Department of Finance Copenhagen Business School Rosenorns, Frederiksberg Denmark.

Thornsbury, S., Jerardo, A., Wells, H.F., 2012. Vegetables and pulses outlook. Economic Research Service, United States Department of Agriculture. VGS-351

Toaha, M., 1974. Estimation of marketing margins and measurement of seasonal price variations of selected agricultural commodities in Sindh province of Pakistan. Sindh Agriculture College, Tando Jam, Pakistan.

Tobin, J., 1993. Price flexibility and output stability: an old Keynesian view. Journal of Economic Perspectives, 7(1), 45-65.

West, J., 2012. Long-dated agricultural futures price estimates using the seasonal Nelson-Siegel model. International Journal of Business and Management, 7(3), 78-93. 